\title{
Pichia cellobiosa, Candida cariosilignicola, and Candida succiphila, New Species of Methanol-Assimilating Yeasts
}

\author{
J. D. LEE AND K. KOMAGATA \\ Institute of Applied Microbiology, University of Tokyo, Bunkyo-ku, Tokyo 113, Japan
}

In the course of a taxonomic study of methanol-assimilating yeasts, a number of isolates were obtained from various natural habitats in Japan, and from these three new species, Pichia cellobiosa, Candida cariosilignicola, and Candida succiphila, have been described. $P$. cellobiosa differs from the related species Pichia castillae with respect to fermentation and assimilation of sugars, biotin requirement for growth, and lower maximum temperature for growth. C. cariosilignicola differs from the related species Torulopsis apicola and Torulopsis bombicola with respect to assimilation of sugars and proton magnetic resonance spectra of cell wall mannans. C. succiphila is similar to $C$. cariosilignicola but differs from it with respect to fermentation and assimilation of sugars, lower maximum temperature for growth, higher deoxyribonucleic acid base composition, and proton magnetic resonance spectra of cell wall mannans. The type strains of these new species are KL 1 (=IAM 12481), KL 24 (=IAM 12484), and KL 30 (=IAM 12489), respectively. Cultures of the type strains have been deposited in the Institute of Applied Microbiology Culture Collection Center, University of Tokyo, Tokyo, Japan, and the Inst:tute for Fermentation, Osaka, Japan.

Since Ogata et al. (16) reported a methanolassimilating yeast in 1969 , a number of such yeasts have been described $(1-3,8,9,11,14,15$, $17,18,21,23,28$ ). Hazeu et al. (7) examined methanol-assimilation in type strains preserved at the Centraalbureau voor Schimmelcultures and reported assimilation by the type strains of 15 species in the genera Hansenula, Pichia, Torulopsis, and Candida. However, the systematics of methanol-assimilating yeasts have not been studied in detail. Therefore, we attempted to isolate methanol-assimilating yeasts from a wide variety of natural sources in Japan in order to compare them taxonomically with the presently described methanol-assimilating yeast species. During the investigation, 10 of the new isolates were identified as belonging to three new species, which are named and described here. A taxonomic study on methanol-assimilating yeasts, including the new species named and described here, will be reported in the future.

\section{MATERIALS AND METHODS}

Isolation of yeasts. Yeasts were isolated from various sources by using a methanol medium containing the following: $\left(\mathrm{NH}_{4}\right)_{2} \mathrm{SO}_{4}, 3 \mathrm{~g} ; \mathrm{KH}_{2} \mathrm{PO}_{4}, 4 \mathrm{~g} ; \mathrm{MgSO}_{4}$. $7 \mathrm{H}_{2} \mathrm{O}, 0.5 \mathrm{~g} ; \mathrm{NaCl}, 0.2 \mathrm{~g}$; ferric citrate, $3 \mathrm{mg} ; \mathrm{CaCl}_{2}$. $2 \mathrm{H}_{2} \mathrm{O}, 3 \mathrm{mg} ; \mathrm{MnSO}_{4} \cdot 4 \mathrm{H}_{2} \mathrm{O}, 0.5 \mathrm{mg} ; \mathrm{ZnSO}_{4} \cdot 7 \mathrm{H}_{2} \mathrm{O}, 0.5$ $\mathrm{mg}$; $\mathrm{CuSO}_{4} \cdot 5 \mathrm{H}_{2} \mathrm{O}, 0.05 \mathrm{mg}$; yeast extract, $0.2 \mathrm{~g}$; methanol, $10 \mathrm{mil}$; chloramphenicol, $50 \mathrm{mg}$; and distilled water, $1,000 \mathrm{ml}$. The $\mathrm{pH}$ was 4.5 or was adjusted to 6.6 with $\mathrm{Na}_{2} \mathrm{HPO}_{4}$. About $1 \mathrm{~g}$ of source material was inoculated into $10 \mathrm{ml}$ of medium; incubation was at $30^{\circ} \mathrm{C}$ with shaking. The enrichment culture technique was used for isolation, and pure cultures were obtained by the conventional streaking technique. The strains isolated and their sources are listed in Table 1.

Characterization of yeasts. The methods used to characterize the isolates were primarily those reported by Wickerham (24) and Lodder (12). Vitamin requirements were determined by the method of Komagata and Nakase (10). Deoxyribonucleic acid was isolated and purified by the procedure of Cryer et al. (4), and deoxyribonucleic acid base compositions were calculated from thermal denaturation temperatures by the formula of Marmur and Doty (13). The ubiquinone systems were determined by the method of Yamada and Kondo (25). Isolations and purifications of mannans from yeast cells were carried out as previously reported by Gorin and Spencer (5). Proton magnetic resonance (PMR) spectra of the mannans were obtained by using a JNM-4H 100 spectrometer equipped with a temperature control unit; these spectra were determined from $0.4 \mathrm{ml}$ of a $\mathrm{D}_{2} \mathrm{O}$ solution containing $80 \mathrm{mg}$ of mannan at $70^{\circ} \mathrm{C}$, using 3-(trimethylsilyl)propane sulfonic acid (sodium salt) as an internal standard.

\section{RESULTS AND DISCUSSION}

Three strains (KL 1, KL 2, and KL 5) form hat-shaped ascospores and assimilate galactose, L-sorbose, cellobiose, and a considerable number of other sugars. They resemble Pichia castillae (19) in these characteristics but differ from it in that they ferment glucose and cellobiose, do not assimilate maltose, melibiose, or raffinose, re- 
TABLE 1. Sources of the strains studied

\begin{tabular}{|c|c|}
\hline Strain & Source \\
\hline KL 1 & Soil, Chiba Prefecture \\
\hline $\mathrm{KL} 2$ & Soil, Chiba Prefecture \\
\hline KL 5 & Soil, Metropolitan Tokyo \\
\hline KL 24 & $\begin{array}{l}\text { Decayed timbers, Yamanashi Pre- } \\
\text { fecture }\end{array}$ \\
\hline KL 14 & Soil, Yamanashi Prefecture \\
\hline KL 16 & $\begin{array}{l}\text { Sap of peach tree, Yamanashi Pre- } \\
\text { fecture }\end{array}$ \\
\hline KL 21 & $\begin{array}{l}\text { Sap of peach tree, Yamanashi Pre- } \\
\text { fecture }\end{array}$ \\
\hline KL 22 & Peach, Yamanashi Prefecture \\
\hline KL 30 & $\begin{array}{l}\text { Sap of peach tree, Yamanashi Pre- } \\
\text { fecture }\end{array}$ \\
\hline KL 31 & Peach, Yamanashi Prefecture \\
\hline
\end{tabular}

quire biotin for growth, and have a lower maximum temperature for growth. Since most Pichia species with hat- or Saturn-shaped ascospores possess Q8 (26) and most of the species in the genus Hansenula possess Q7 (26), strains KL 1, KL 2, and KL 5 seem to be unique in that they possess a ubiquinone system composed of both Q8 (major component) and Q7 (minor component) and thus appear to be intermediate between Pichia and Hansenula. These three strains are here regarded as belonging to a new species, for which the name Pichia cellobiosa is proposed.

Strain KL 24 is asporogenous, has globose or oval cells, does not form pseudomycelia or true mycelia, and does not produce manifest carotenoid pigments; furthermore, it does not assimilate inositol and produces no starch. These characteristics fit those of the genus Torulopsis Berlese (22). Yarrow and Meyer (27) proposed an amendment of the description of the genus Candida Berkhout to allow for nonhyphal species. In accordance with the amended description, strain KL 24 was classified in the genus Candida. With respect to the fermentation of sugars, strain KL 24 resembles Torulopsis apicola (6) and Torulopsis bombicola (20), but it differs from them by its assimilation of trehalose, D-xylose, D-arabinose, and L-arabinose and its PMR spectrum of cell wall mannan (20). Strain KL 24 is here regarded as a member of a new species, Candida cariosilignicola.

Six strains (KL 14, KL 16, KL 21, KL 22, KL 30 , and KL 31) resemble strain KL 24 in morphological and cultural characteristics, but they differ from it and other related strains in the fermentation and assimilation of sugars. These six strains cannot grow at $37^{\circ} \mathrm{C}$, their deoxyribonucleic acid base compositions are about $5 \%$ higher than that of strain KL 24, and the PMR spectra of their cell wall mannans are different from the PMR spectrum of strain KL 24 cell wall mannan. Mating was not found in combinations of these six strains, which are here placed in a new species, Candida succiphila. Descriptions of these three newly recognized species follow.

Pichia cellobiosa sp. nov. (cel.lo.bi.o'sa. M.L. adj. cellobiosus pertaining to cellobiose, a sugar derived from cellulose.) This description is based on strains $\mathrm{KL} 1, \mathrm{KL} 2$, and $\mathrm{KL} 5$, which possess the same characteristics.

Latin diagnosis. In medio liquido cellulae subovoideae aut ovoideae, $(1.8-4.5) \times(2.7-5.4)$ $\mu \mathrm{m}$, singulae aut binae. Sedimentum formatur. Cultura in agaro flavoglauca, glabra, butyrosa, margine undulato. Pseudomycelium non formatur. Asci inconjugati fiunt, habentes 3 aut 4 sporos pileiformos in quoque asco, asci rumpunter. Species homothallica.

D-Glucosum et cellobiosum (lente) fermentantur at non D-galactosum, saccharosum, maltosum, lactosum, raffinosum, melibiosum, nec trehalosum.

D-Glucosum, D-galactosum, L-sorbosum, cellobiosum, trehalosum, D-xylosum, L-arabinosum, D-arabinosum, D-ribosum, methanolum, ethanolum, glycerolum, erythritolum, ribitolum, galactitolum, mannitolum, glucitolum, salicinum, acidum succinicum (variabile), et acidum citricum (variabile) assimilantur at non saccharosum, maltosum, lactosum, melibiosum, raffinosum, melezitosum, inulinum, amylum solubile, L-rhamnosum, $\alpha$-methyl-D-glucosidum, DLacidum lacticum, nec inositolum.

Nitras kalicus non assimilatur.

Biotinae necessariae ad crescentiam.

Maxima temperatura crescentiar: $35-36^{\circ} \mathrm{C}$.

Proportio molaris $\mathrm{G}+\mathrm{C}$ in acido deoxyribonucleico: $36.9 \mathrm{~mol} \%$.

Typus isolatus ex solum Chibaensis, depositus in Institute of Applied Microbiology Culture Collection Center, University of Tokyo (IAM 12481), et Institute for Fermentation, Osaka, Japan (IFO 1909).

Description. Growth in glucose-yeast extract-peptone water: After 3 days at $25^{\circ} \mathrm{C}$, the cells are oval or ovoid, 1.8 to 4.5 by 2.7 to $5.4 \mu \mathrm{m}$ (Fig. 1A). A pellicle is not formed.

Growth on YM agar: After 1 month at $20^{\circ} \mathrm{C}$, a streak culture is brownish white, smooth, and butyrous and has an undulate margin.

Growth on yeast morphology agar: After 1 month at $20^{\circ} \mathrm{C}$, a streak culture is yellowish white, smooth with slight radial striations, and butyrous and has an undulate margin.

Dalmau plate culture on potato dextrose agar: Pseudomycelia are not formed either aerobically or anaerobically.

Formation of ascospores: Ascospores are formed readily on V-8 vegetable agar and YM 

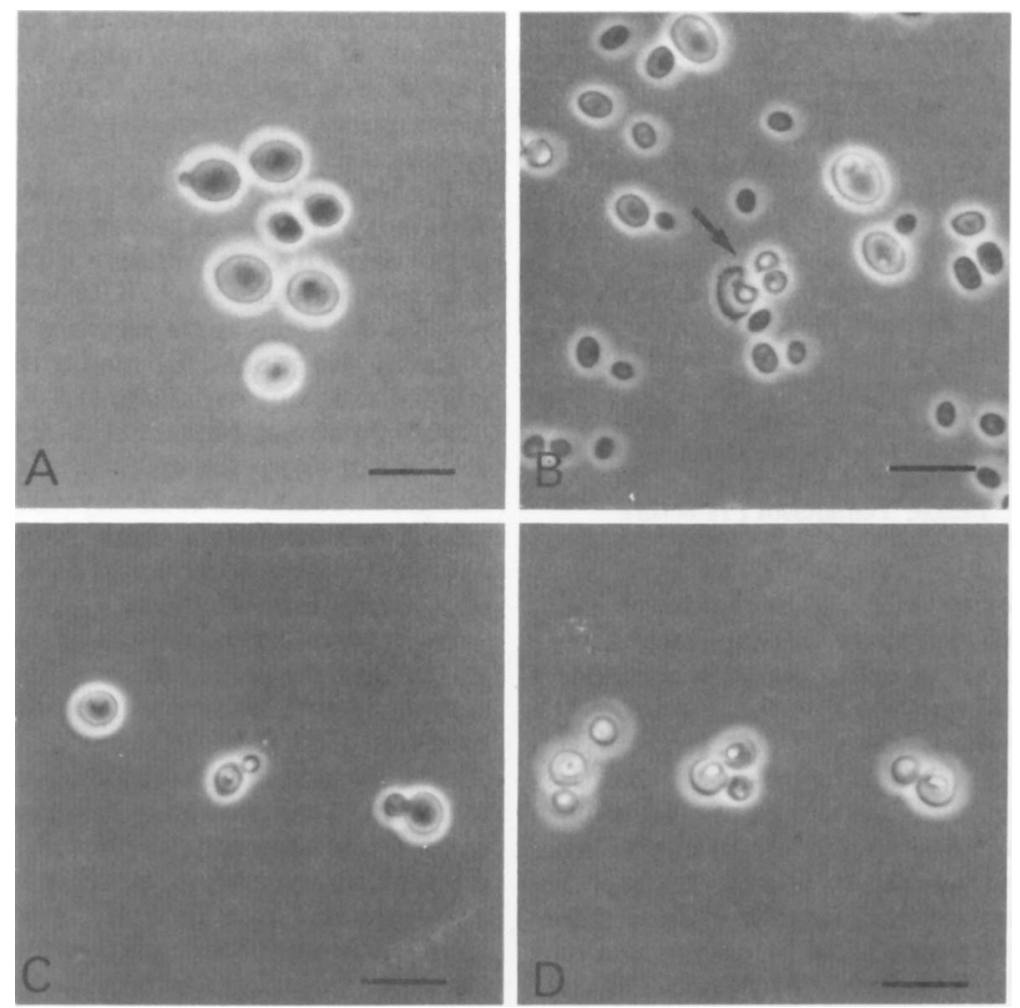

Fig. 1. Cells of P. cellobiosa, C. cariosilignicola, and C. succiphila. (A) Vegetative cells of P. cellobiosa grown in glucose-yeast extract-peptone water for 3 days at $25^{\circ} \mathrm{C}$. (B) Ascospores of P. cellobiosa grown on YM agar for 7 days at $25^{\circ} \mathrm{C}$. Arrow indicates hat-shaped ascospores. (C) Vegetative cells of C. cariosilignicola grown in glucose-yeast extract-peptone water for 3 days at $25^{\circ} \mathrm{C}$. (D) Vegetative cells of C. succiphila grown in glucose-yeast extract-peptone water for 3 days at $25^{\circ} \mathrm{C}$. The bars represent 10 im in all illustrations.

agar after 5 to 7 days at $25^{\circ} \mathrm{C}$. Strongly sporulating cultures appear brownish red, presumably because of the pigmentation of the ascospores. Ascus formation is usually preceded by the fusion of independent cells, which frequently form conjugation tubes, or less frequently by somatogamous autogamy. The asci contain three to four rather small hat-shaped ascospores with short brims (Fig. 1B). The asci rupture at maturity, releasing the spores soon after formation. The strains examined are homothallic.

Fermentation: D-Glucose and cellobiose (latent) are fermented. D-Galactose, saccharose, maltose, lactose, raffinose, and melibiose are not fermented.

Assimilation of carbon compounds: D-Glucose, D-galactose, L-sorbose, cellobiose, trehalose, Dxylose, L-arabinose, D-arabinose, D-ribose, methanol, ethanol, glycerol, erythritol, ribitol, galactitol, D-mannitol, D-glucitol, and salicin are assimilated. Assimilations of succinate and citrate are variable. Saccharose, maltose, lactose, melibiose, raffinose, melezitose, inulin, soluble starch, L-rhamnose, $\alpha$-methyl-D-glucoside, DLlactate, and inositol are not assimilated.

Assimilation of potassium nitrate: Negative.

Growth in vitamin-free medium: Negative. Biotin is required for growth.

Growth on $50 \%(\mathrm{wt} / \mathrm{wt})$ glucose yeast extract agar: Negative.

Sodium chloride tolerance: Tolerates 9 to $10 \%$ $\mathrm{NaCl}$.

Maximum temperature for growth: 35 to $36^{\circ} \mathrm{C}$.

Production of starchlike substance: Negative. Gelatin liquefaction: Negative.

Urease and extracellular deoxyribonuclease activity: Negative.

Guanine plus cytosine content of nuclear deoxyribonucleic acid: $36.9 \mathrm{~mol} \%$.

Ubiquinone system: Q8 (minor component, Q7).

PMR spectrum of cell wall mannan: Group 9$\mathrm{d}$ of Spencer and Gorin (Fig. 2).

Type strain: KL 1, which was isolated in 1977 from soil from Chiba Prefecture, Japan. Cultures 


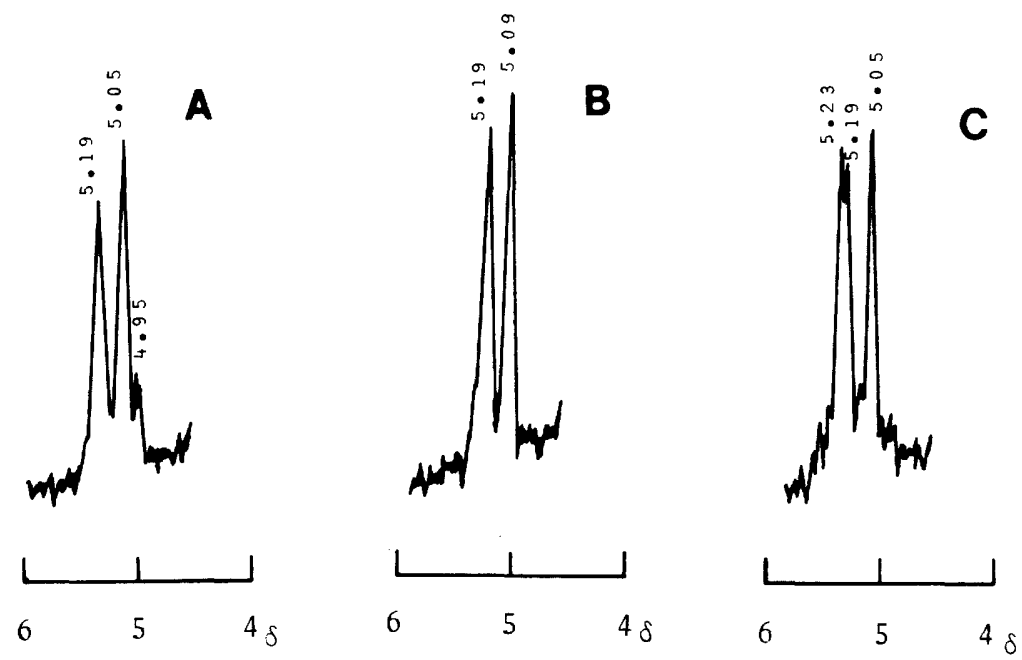

Fig. 2. PMR spectra of cell wall mannans. (A) P. cellobiosa. (B) C. cariosilignicola. (C) C. succiphila.

of this strain have been deposited in the Institute of Applied Microbiology Culture Collection Center, University of Tokyo, with the accession number 12481 and in the Institute for Fermentation, Osaka, under the number 1909.

Candida cariosilignicola sp. nov. (ca.ri.o.si.lig.ni' co.la. L. adj. cariosus decayed, rotted; L. noun lignum wood; L. -cola dweller; M.L. fem. n. cariosilignicola decayed-wood dweller or inhabitant.) The description of this species is based on a single strain, KL 24.

Latin diagnosis. In medio liquido cellulae rotundae aut ovoideae, $(1.8-2.7) \times(1.8-3.0) \mu \mathrm{m}$, singulae, binae, aut in catenis brevis. Sedimentum formatur. Cultura in agaro flavoglauca, glabra, butyrosa, vel semimucosa, nitida, margine undulato. Pseudomycelium non formatur.

D-Glucosum, saccharosum, et raffinosum (1/ 3) fermentantur at non D-galactosum, maltosum, lactosum, cellobiosum, melibiosum, nec trehalosum.

D-Glucosum, L-sorbosum, saccharosum, trehalosum, raffinosum, D-xylosum, L-arabinosum, D-arabinosum, D-ribosum, L-rhamnosum, methanolum, ethanolum, glycerolum, erythritolum, ribitolum, galactitolum (tarde et exigue), D-mannitolum, D-glucitolum, et acidum citricum assimilantur at non D-galactosum, maltosum, cellobiosum, lactosum, melibiosum, melezitosum, inulinum, amylum solubile, $\alpha$-methyl-D-glucosidum, salicinum, DL-acidum lacticum, acidum succinicum, nec inositolum.

Nitras kalicus assimilatur.

Biotinae necessariae ad crescentiam.

Maxima temperatura crescentiar: $41-42^{\circ} \mathrm{C}$.

Proportio molaris $\mathrm{G}+\mathrm{C}$ in acido deoxyribonucleico: $35.1 \mathrm{~mol} \%$.

Typus isolatus ex calinoso lignum Yamanash- iensis, depositus in Institute of Applied Microbiology Culture Collection Center, University of Tokyo (IAM 12484), et Institute for Fermentation, Osaka (IFO 1910).

Description. Growth in glucose-yeast extract-peptone water: After 3 days at $25^{\circ} \mathrm{C}$, the cells are globose or spherical, 1.8 to 2.7 by 1.8 to $3.0 \mu \mathrm{m}$ (Fig. 1C). A pellicle is not formed.

Growth on YM agar and yeast morphology agar: After 1 month at $20^{\circ} \mathrm{C}$, a streak culture is yellowish white, smooth, butyrous to slightly mucoid, and glistening and has an undulate margin.

Dalmau plate culture on potato dextrose agar: Pseudomycelia are not formed either aerobically or anaerobically.

Formation of ascospores: Ascospores are not formed on YM agar, Gorodkowa agar, V-8 vegetable agar, or Kleyn acetate agar.

Fermentation: D-Glucose, saccharose, and raffinose ( $1 / 3)$ are fermented. $D$-Galactose, maltose, cellobiose, lactose, and melibiose are not fermented.

Assimilation of carbon compounds: D-Glucose, L-sorbose, saccharose, trehalose, raffinose, D-xylose, L-arabinose, D-arabinose, D-ribose, L-rhamnose, methanol, ethanol, glycerol, erythritol, ribitol, galactitol (slow and weak), D-mannitol, Dglucitol, and citrate are assimilated. D-Galactose, maltose, cellobiose, lactose, melibiose, melezitose, inulin, soluble starch, $\alpha$-methyl-D-glucoside, salicin, DL-lactate, succinate, and inositol are not assimilated.

Assimilation of potassium nitrate: Positive.

Growth in vitamin-free medium: Negative. Biotin is required for growth.

Growth on $50 \%$ (wt/wt) glucose yeast extract agar: Negative. 
Sodium chloride tolerance: Tolerates 6 to $7 \%$ $\mathrm{NaCl}$.

Maximum temperature for growth: 41 to $42^{\circ} \mathrm{C}$.

Production of starchlike substance: Negative.

Gelatin liquefaction: Negative.

Urease and extracellular deoxyribonuclease activity: Negative.

Guanine plus cytosine content of nuclear deoxyribonucleic acid: $35.1 \mathrm{~mol} \%$.

Ubiquinone system: Q7.

PMR spectrum of cell wall mannan: Group 9b of Spencer and Gorin (Fig. 2).

Type strain: KL 24, which was isolated in 1977 from decayed timber in Yamanashi Prefecture, Japan. Cultures of this strain have been deposited in the Institute of Applied Microbiology Culture Collection Center, University of Tokyo, with the accession number 12484 and in the Institute for Fermentation, Osaka, under the number 1910.

Candida succiphila sp. nov. (suc.ci.phi'la. L. noun succus sap; Gr. adj. philus loving; M.L. adj. succiphilus sap-loving.) The description of this species is based on strains $\mathrm{KL} \mathrm{14}, \mathrm{KL} \mathrm{16}$, KL 21, KL 22, KL 30, and KL 31, which possess the same characteristics.

Latin diagnosis. In medio liquido cellulae rotundae aut ovoideae, $(1.8-2.7) \times(1.8-3.0) \mu \mathrm{m}$, singulae, binae aut in catenis brevis. Sedimentum formatur. Cultura in agaro flavoglauca, glabra, butyrosa, nitida vel seminitida, margine undulato. Pseudomycelium non formatur.

D-Glucosum, D-galactosum, et cellobiosum (lente) fermentantur at non saccharosum, maltosum, lactosum, raffinosum, melibiosum, nec trehalosum.

D-Glucosum, D-galactosum, L-sorbosum, cellobiosum, trehalosum, D-xylosum, L-arabinosum, D-arabinosum, D-ribosum, L-rhamnosum, methanolum, ethanolum, glycerolum, erythritolum, ribitolum, galactitolum (lente aut exigue), D-glucitolum, et salicinum assimilantur at non saccharosum, maltosum, lactosum, melibiosum, raffinosum, melezitosum, inulinum, amylum solubile, $\alpha$-methyl-D-glucosidum, DLacidum lacticum, acidum succinicum, acidum citricum, nec inositolum.

Nitras kalicus non assimilatur.

Biotinae necessariae ad crescentiam.

Maxima temperatura crescentiar: $35-36^{\circ} \mathrm{C}$.

Proportio molaris $\mathrm{G}+\mathrm{C}$ in acido deoxyribonucleico: $40.9 \mathrm{~mol} \%$.

Typus isolatus ex cerasus stemma Yamanashiensis, depositus in Institute of Applied Microbiology Culture Collection Center, University of Tokyo (IAM 12489), et Institute for Fermentation, Osaka (IFO 1911).
Description. Growth in glucose-yeast extract-peptone water: After 3 days at $25^{\circ} \mathrm{C}$, cells are globose or spherical, 1.8 to 2.7 by 1.8 to 3.0 $\mu \mathrm{m}$ (Fig. 1D). A pellicle is not formed.

Growth on YM agar and yeast morphology agar: After 1 month at $20^{\circ} \mathrm{C}$, a streak culture is yellowish white, smooth, butyrous, and slightly glistening with an undulate margin.

Dalmau plate culture on potato dextrose agar: Pseudomycelia are not formed either aerobically or anaerobically.

Formation of ascospores: Ascospores are not formed on YM agar, Gorodkowa agar, V-8 vegetable agar, or Kleyn acetate agar.

Fermentation: D-Glucose, D-galactose, and cellobiose (latent) are fermented. Saccharose, maltose, lactose, raffinose, and melibiose are not fermented.

Assimilation of carbon compounds: D-Glucose, D-galactose, L-sorbose, cellobiose, trehalose, Dxylose, L-arabinose, D-arabinose, D-ribose, Lrhamnose, methanol, ethanol, glycerol, erythritol, ribitol, galactitol (latent or weak), D-mannitol, D-glucitol, and salicin are assimilated. Saccharose, maltose, lactose, melibiose, raffinose; melezitose, inulin, soluble starch, $\alpha$-methyl-Dglucoside, DL-lactate, succinate, citrate, and inositol are not assimilated.

Assimilation of potassium nitrate: Negative.

Growth in vitamin-free medium: Negative.

Biotin is required for growth.

Growth on $50 \%$ (wt/wt) glucose yeast extract agar: Negative.

Sodium chloride tolerance: Tolerates 7 to $8 \%$ $\mathrm{NaCl}$.

Maximum temperature for growth: 35 to $36^{\circ} \mathrm{C}$.

Production of starchlike substance: Negative.

Gelatin liquefaction: Negative.

Urease and extracellular deoxyribonuclease activity: Negative.

Guanine plus cytosine content of nuclear deoxyribonucleic acid: $40.9 \mathrm{~mol} \%$.

Ubiquinone system: Q7.

PMR spectrum of cell wall mannan: Group 9-a of Spencer and Gorin (Fig. 2).

Type strain: KL 30, which was isolated in 1977 from the sap of a peach tree in Yamanashi Prefecture, Japan. Cultures of this strain have been deposited in the Institute of Applied Microbiology Culture Collection Center, University of Tokyo, with the accession number 12489 and in the Institute for Fermentation, Osaka, under the number 1911.

\section{ACKNOWLEDGMENT}

We thank S. Goto, Yamanashi University, for his encouragement and invaluable discussions. 


\section{REPRINT REQUESTS}

Address reprint requests to: Dr. K. Komagata, Institute of Applied Microbiology, University of Tokyo, Yayoi 1-1-1, Bunkyo-ku, Tokyo 113, Japan.

\section{LTTERATURE CITED}

1. Asai, Y., N. Makiguchi, M. Shimada, and Y. Kurimura. 1976. New species of methanol-assimilating yeasts. J. Gen. Appl. Microbiol. 22:197-202.

2. Asthana, H., A. E. Humphrey, and V. Moritz. 1971. Growth of yeast on methanol as the sole carbon substrate. Biotechnol. Bioeng. 13:923-929.

3. Craveri, R., v. Cavazzoni, P. G. Sarra, G. Succi, L. Molteni, G. Cardini, and L. Di Fiore. 1976. Taxonomical examination and characterization of a methanol-utilizing yeast. Antonie van Leeuwenhoek J. Microbiol. Serol. 42:533-540.

4. Cryer, D. R., R. Eccleshall, and J. Marmur. 1975. Isolation of yeast DNA. Methods Cell Biol. 12:39-44.

5. Gorin, P. A. J., and J. F. T. Spencer. 1970. Proton magnetic resonance spectroscopy-an aid in identification and chemotaxonomy of yeasts. Adv. Appl. Microbiol. 13:25-89.

6. Hajsig, M. 1958. Torulopsis apicola nov. spec., new isolates from bees. Antonie van Leeuwenhoek J. Microbiol. Serol. 24:18-22.

7. Hazeu, H. J. C. De Bryun, and P. Bos. 1972. Methanol assimilation by yeasts. Arch. Mikrobiol. 87:185-188.

8. Henninger, W., and S. Windisch. 1975. Pichia lindnerii sp. n., eine neue Methanol assimilierende Hefe aus Erde. Arch. Microbiol. 105:47-48.

9. Kato, K., Y. Kurimura, N. Makiguchi, and Y. Asai. 1974. Determination of methanol strongly assimilating yeasts. J. Gen. Appl. Microbiol. 20:123-127.

10. Komagata, K., and T. Nakase. 1967. Microbiological studies on frozen foods. V. General properties of yeasts isolated from frozen foods. J. Food Hyg. Soc. Jpn. 8: 53-57.

11. Levine, D. W., and C. L. Cooney. 1973. Isolation and characterization of a thermotolerant methanol-utilizing yeast. Appl. Microbiol 26:982-990.

12. Lodder, J. (ed.). 1970. The yeasts, a taxonomic study. North Holland Publishing Co., Amsterdam.

13. Marmur, J., and P. Doty. 1962. Determination of the base composition of deoxyribonucleic acid from its thermal denaturation temperature. J. Mol. Biol. 5:109-118.

14. Miller, M. W., H. J. Phaff, M. Miranda, W. B. Heed, and W. T. Stanmer. 1976. Torulopsis sonorensis, a new species of the genus Torulopsis. Int. J. Syst. Bacteriol. 26:88-91.

15. Minami, K., M. Yamamura, S. Shimizu, K. Ogawa, and N. Sekimi. 1978. A new methanol-assimilating, high productive, thermophilic yeast. J. Ferment. Technol. 56:1-7.

16. Ogata, K., H. Nishikawa, M. Ohsugi, and T. Tochikura. 1970. Studies on the production of yeast. I. A yeast utilizing methanol as a sole carbon source. J. Ferment. Technol. 48:389-396.

17. Oki, T., K. Kouno, A. Kitai, and A. Ozaki. 1972. New yeasts capable of assimilating methanol. J. Gen. Appl. Microbiol. 18:295-305.

18. Sahm, H., and F. Wagner. 1972. Mikrobielle Verwertung von Methanol. Isolierung und Charakterisierung der Hefe Candida boidinii. Arch. Mikrobiol. 84:29-42.

19. Santa Maria, J. 1970. Pichia castillae, nov. spec., aislada de insetors. Inst. Nac. Invest. Agron. (Spain) Cuad. 30: 51-55.

20. Spencer, J. F. T., and P. A. J. Gorin. 1970. Torulopsis bombicola sp. n. Antonie van Leeuwenhoek J. Microbiol. Serol. 36:129-133.

21. Tonomura, K., F. Kanzaki, and A. Kambayashi. 1972. Isolation and characterization of methanol-assimilating yeasts. Rep. Ferment. Res. Inst. (Japan) 41:49-55.

22. van Uden, N., and M. Vidal-Leiria. 1970. Torulopsis Berlese, p. 1235-1309. In J. Lodder (ed.) The yeasts, a taxonomic study. North Holland Publishing Co., Amsterdam.

23. Volfová, O., and P. Pilát. 1974. Studies on methanoloxidizing yeasts. Folia Microbiol. 19:249-256.

24. Wickerham, L. J. 1951. Taxonomy of yeasts. U.S. Dept. Agric. Tech. Bull. 1029:1-56.

25. Yamada, Y., and K. Kondo. 1973. Coenzyme Q system in the classification of the yeast genera Rhodotorula and Cryptococcus, and the yeast-like genera Sporobolomyces and Rhodosporidium. J. Gen. Appl. Microbiol. 19:59-77.

26. Yamada, Y., T. Okada, O. Ueshima, and K. Kondo. 1973. Coenzyme $Q$ system in the classification of the ascosporogenous yeast genera Hansenula and Pichia. J. Gen. Appl. Microbiol. 19:189-208.

27. Yarrow, D., and S. A. Meyer. 1978. Proposal for amendment of the diagnosis of the genus Candida Berkhout nom. cons. Int. J. Syst. Bacteriol. 28:611-615.

28. Yokote, Y., M. Sugimoto, and S. Abe. 1974. Yeasts utilizing methanol as a sole carbon source. J. Ferment. Technol. 52:201-209. 